\title{
Polish Sociology and the Base-Superstructure Debate*
}

\author{
RAY TARAS, Political Science, University of Michigan
}

One of the most important elements in Marx's theory of social formation-and at the same time one which has merited considerable attention in the works of later generations of Marxists-is his structural model of society made up of an economic base and a political and legal superstructure. As Kautsky succinctly put it, 'Without doubt this is the most propagated of all theses contained in the materialist conception of history, for it has had a profound impact on and is accepted as central to this conception. Yet this thesis has been the subject of unusual interpetations and misunderstandings'. ${ }^{1}$

For non-Marxist critics this cornerstone of the theory of social formation has been regarded as its weak link which, if undermined, could bring down the entire construct. Critics are quick to point out that among Marxists themselves there is disagreement as to what really constitutes the economic base, what the superstructure consists of, and what the nature of their relationship really is. As far back as the turn of the century, Bernstein was trying to prove that Engels' view of the relationship, described in several letters he wrote in the eighteen-nineties, was substantially at odds with that of Marx, presented in $A$ Contribution to the Critique of Political Economy. Somewhat later critics hastened to demonstrate the contradictions between the economic determinism of Kautsky's interpretation of the model and the overriding importance that Lenin attached to the political superstructure. More recently the analytical value of the whole model has come into question as Marxists and non-Marxists alike seem to dismantle and discard its components piece by piece.

The stress on individual elements making up the model has differed in time and, with it, the very nature of the debate has changed. Whereas for Lenin 'Marx devoted most of his attention to an analysis of the importance of the economic system', ${ }^{2}$ second-generation Marxists like Plechanov, Labriola and even Kautsky took a more 'organic' view of base-superstructure relations, de-emphasized the mythicized determinism of the economic base, and devoted greater attention to the issue

\section{* Received 15.4.81}

1 K. Kautsky, Materialistyczne pojmowanie dziejow, Vol. 1, Warsaw 1963, p. 531.

2 V. I. Lenin, Marks, Engels, Marksizm, Warsaw 1949, p. 61. 
of the autonomy of ideas in the model. The debate became more philosophical and was epitomized in the works of two other classicallyoriented Marxist thinkers-Lukacs (and his concept of 'totality') and Gramsci (and his 'historical bloc' approach). The success of the Bolshevik revolution drew the attention of Marxist theorists to political factors, and the writings of Lenin and Stalin touching on historical development placed added weight on the concepts of political power, political organization and consciousness. After the last war the debate took a more sociological turn. The principal protagonists have been sociologists, and 'sociologizing' philosophers such as Aron, Bell, Althusser, Gouldner and representatives of the Frankfurt School. The reason for this, according to a leading Polish sociologist, was that sociology now performed a role similar to that played earlier by classical political economy: it gathered and interpreted information about society, it formulated laws about social development and, with the help of 'socio-technics', it tried to affect society. ${ }^{3}$

At the same time as Western sociology has been engaged in a debate on the issue, so too has sociology in the socialist states. Here, however, it has been influenced by two major considerations which play a secondary part in the West. Firstly the discussion has been related directly to the way socialism has developed (or, employing the terminology of the voluntarist viewpoint, it has been applied) in these countries. Secondly, it has focussed on the problem of how correctly to interpret the Marxian model of base and superstructure: there is no question of it being rejected outright. Given these additional factors, the debate among sociologists in a socialist state tends to be more meaningful for and revealing about that society than the kind of 'academic' polemics than go on in the West, as innovative and fascinating as they sometimes are.

For this reason alone it seems worth examining the various approaches to the Marxist theory of social formation taken by sociologists in a socialist country. The 'politics' involved in the approaches says much, too, about the type of intellectual environment that has arisen here. But there are several other reasons why it would prove valuable to consider the controversy on this issue among scholars in socialist states. Firstly, in identifying the primacy of either economic relations or political and institutional factors in affecting social development, a crucial philosophical choice is made. 'Economism' implies a more determinist view of history; the primacy of political factors suggests a more voluntarist approach. In its application to a socialist system, a modular form of economism may entail a relinquishment of the exercise of political power by the state. A modular voluntarist approach, on the other hand, may signify wholesale tampering with economic relations by the politi-

3 W. Morawski, "Marksizm a teorie postindustrialnego spoleczenstwa', in W. Wesolowski (ed.), Marksizm i procesy rozwoju spolecznego, Warsaw 1979, p. 677. 
cal leadership. Thus the very nature of socialism is being considered. Secondly such an examination may help establish how profound the controversy has been. Have the interpretations given by the participants been polarized sufficiently to claim that distinct schools of thought have evolved concerning the model of social formation? Or has the extent of disagreement been exaggerated? Have modular versions of economism and voluntarism evolved or not? Thirdly, an account of the debate may show whether some kind of pattern, or historical trend, can be identified. Has the importance of different constituent variables of the model been related to developments in society? Along the way have new factors had to be introduced into the classic model? Or is it, in its original form, to a large extent still valid today? Finally, following on from the third point, in pursuing the debate we may help clarify for ourselves the type of analytic model which might best serve to describe the dynamics of socialist states. Are these subject to the same principles of basesuperstructure relations as societies in earlier phases of formation? That is, is the model characterized by a " "universal" determinism ... meant to apply to any class-exploitative system anywhere, whether or not capitalist', as Gouldner suggests. ${ }^{4}$ Or are these societies qualitatively different to such a degree that different tools of analysis are needed to study them? If so, in what way does the model of base and superstructure remain useful?

Although ideally one would examine approaches to the theory of social formation by as many theorists in as many socialist countries as possible, this is clearly not feasible. This brief study focusses, therefore, on how Polish sociology, and related disciplines which occasionally 'sociologize', have treated the issue. Polish sociology has made substantial and well-known theoretical contributions to the discipline since Znaniecki, and to Marxism since the First International. In relation to Marx's model of social formation, the debate among Polish scholars has been extremely lively and diversified. But it would equally be worth looking at the debate in other socialist states simply to observe the degree of consensus or conflict that has occurred among its Marxist theorists and to identify the main currents-such as deterministdoctrinaire, organic-liberal, voluntarist-Stalinist-which have dominated thinking at a particular time. For different interpretations of the classic model may, as we have suggested, represent different conceptions of socialism.

Before beginning our account, we ought to bear in mind a point on Marx's general methodology made by the sociologist Julian Hochfeld. He writes: 'Ultimately the literary output of Marx and Engels, though very rich, includes relatively few areas in which a particular theoretical whole is presented homogeneously, systematically and comprehensive-

4 A. W. Gouldner, The Two Marxisms, New York 1980, p. 236. 
1y'..$^{5}$ The result has been to give later generations of Marxists broad scope for interpretation, inference and extrapolation from the sketchy theoretical models constructed by Marx and Engels. By referring to selected fragments from their voluminous, often disparate works dealing with a multiplicity of subjects-in this way seeking to arrive at a 'theoretical whole' based on them-subsequent Marxist-oriented approaches were bound to be 'full of contradictions and inconsistencies', as Gramsci noted. The lengthy debate among Polish scholars furnishes ample evidence of this. We turn now to a brief examination of some of these viewpoints.

\section{THE DIALECTIC BETWEEN STALINISM AND ANTI-STALINISM}

The period with which we are concerned is post-war Poland, in which the foundations of a socialist system had already been laid. But the contribution of a relatively unknown Polish sociologist writing much earlier merits attention. In his short life Kazimierz Kelles-Krauz (18721905) completed only a small part of what he had planned to be a comprehensive analysis of economic materialism, depicting the dialectical relationship between economics, ethics, law, politics and philosophy. What he achieved was in fact a general outline of these relationships, and it offers an early systematic study of economic materialism dealing with the issues of concern to early Marxist scholars.

Kelles-Krauz adopted a rather strict interpretation of the determinance of social life by economic relations. 'Ethics, law, politics, religion, art, science, philosophy-all have a utilitarian source and existence as a result of which they cannot stand in opposition to the means of production but have to adapt themselves to them' ${ }^{6}{ }^{6}$ He viewed society as a multi-tiered construct, as a mass consisting of a number of external layers, the fundament (or core) of which were economic relations. Thus the economic structure supported a superstructure in which ethics served as a basis for law: politics, science and art for philosophy; and so on. The economy itself rested upon production, while the means of production depended upon technology. According to Kelles-Krauz, all social phenomena could be classified in terms of the 'degree of their formality'. The economic structure represented the first degree of formality, followed by ethics and law (norms governing social behaviour), then science, art, religion and philosophy (social logic). In this way biological needs were satisfied by economic activity, ethics ensured that the economy functioned properly, law strengthened ethical norms, and

5 J. Hochfeld, Studia o marksowskiej teorii spoleczenstwa, Warsaw 1963, p. 149. This applies equally to the Marxian concept of ideology. The concept has been the subject of so many different interpretations that it ought to be treated separately and will not be considered in this paper.

6 K. Kelles-Krauz, Pisma wybrane, Vol. 1, Warsaw 1962, p. 17. 
political authority guaranteed that the legal system was respected. ${ }^{7}$ Although Kelles-Krauz never questioned 'his beloved doctrine of the economic monism of history', as Ludwik Krzywicki noted, he accepted that social life was a totality in which mutual dependencies existed among all its elements. For example, economic development could not be understood without reference to legal and philosophical factors. Likewise he realized that superstructural elements did not immediately reflect changes in economic conditions. The latter filtered up gradually through the construction. The higher the degree of formality, the later changes occurred. As a result institutions and doctrines existed long after their social utility and congruence with economic conditions had passed. Not only that: for Kelles-Krauz old ideas never disappeared, in a sense. In his sociological law of retrospection he suggested that ideas governing new social orders always originated in past ideas. For example, communism was based on the idea of primitive communal societies. Kelles-Krauz did not explain why archaic economic relations, which had generated the old ideas, did not reappear also. He sought refuge in Hegelian dialectics: since the future was to be some kind of synthesis, he argued, and since the present was an anti-thesis, then the past had been the thesis where the original idea lay. ${ }^{8}$

After Kelles-Krauz it was some time before the problem of basesuperstructure relations received detailed treatment in Polish sociology. In fact it was Stalin's novel approach, outlined in his Marxism and the Problem of Linguistics which generated controversy (after his death, of course). The apogee of the Stalinist viewpoint was represented in the belief that the superstructure could remake, or simply create, its base. The implications were far-reaching. As Zbigniew Jordan observed, “"Revolutionary Marxism', drawing renewed strength from Stalin's pronouncement and pressed to its logical conclusion, reduced Marxian thought to a system of directives, subject to no restrictive conditions, for interfering with the social and historical process'.${ }^{9}$ In Polish sociological thought the pronouncement was reflected in Adam Schaff's homily that Stalin's theory of base and superstructure constituted 'a floodlight that illuminated the road to revolutionary practice'. ${ }^{10}$

Even after his death, however, a number of Polish social scientists continued to employ Stalin's concept and categories. For the political economist Oscar Lange, for example, the superstructure consisted of all non-economic factors which affected the base or, more precisely, those forms of consciousness which were necessary for a given mode of

7 Ibid., p. 245.

8 Ibid., p. 225. For a broader discussion, see W. Markiewicz, Socjologiczne prawo retrospekcji Kazimierza Kelles-Krauza, Warsaw 1964.

9 Z. A. Jordan, Philosophy and Ideology, Dordrecht 1963, p. 485.

10 A. Schaff, 'Stalinowski wklad w filozofie marksistowska', Mysl Filozoficzna, 2 (8), 1953: $55 f$. 
production to exist. ${ }^{11} \mathrm{He}$ understood social consciousness to mean those social relations which people become conscious of, together with social ideas and psychological attitudes corresponding to these relations. But this was as far as Lange's acceptance of the Stalinist model went. For he argued that all forms of social consciousness, including those relics left after the capitalist system, which were required to maintain the given mode of production constituted part of the superstructure. That is, ideologically relevant forms, such as national culture or family life, as well as ideologically neutral forms, such as science, should not be excluded from the superstructure, as Stalin contended. As the second of his basic sociological laws Lange identified the necessity of congruency between the economic base and the non-economic superstructure. Not all economic relations had to be reflected in the superstructure, he held, but superstructural elements could not be understood without reference to economic processes. Underlying Lange's approach, as that of Stalin, was the identification of base with economic, and superstructure with non-economic relations. For Lange economic relations were those kinds of social relations which were not the object of social consciousness. Non-economic relations were those social relations which people became conscious of, together with social ideas and psychological attitudes corresponding to these relations. ${ }^{12}$ In Marxian thought, according to Lange, superstructure and social consciousness were identical, and they were marked in general by conservatism and inertia. Change occurred only as a result of external stimuli.

Although a departure from Stalin's 'floodlight' model, Lange's position was nevertheless attacked by other Polish scholars as still too voluntarist, with its emphasis on the role played by social consciousness in historical development. As a result, in later editions of his Political Economy, Lange excluded consciousness of social relations from his general definition of social consciousness: consciousness of relations of production and of other social relations was considered simply as the external object of social consciousness, not as a part of it. This implied, for example, that socialist relations of production were not automatically reflected in social consciousness. ${ }^{13}$ By restricting his conception of consciousness to ideologically-relevant and ideologically-neutral forms, Lange simultaneously reduced the importance of non-economic factors in affecting social development. The process of dismantling Stalin's inverted model of social formation had begun.

A much different approach was taken by Hochfeld, writing at about the same time as Lange. He agreed that the dominant means of produc-

11 O. Lange, Ekonomia polityczna, Vol. 1, Warsaw 1963, p. 31.

12 Ibid., p. 30.

13 See S. Kozyr-Kowalski, 'Oskara Langego dwie koncepcje swiadomosci spolecznej i nadbudowy', Studia Socjologiczne, 1, 1980, 323-26. 
tion played the key role in linking all other structures to each other, but that was as much as could be said. In particular the status of the superstructure was unclear. 'Neither Marx, Engels nor Lenin considered the relationship between the concepts of superstructure and social consciousness', Hochfeld observed. ${ }^{14}$ Stalin, he continued, viewed the superstructure exclusively in terms of ideologies and institutions functionally subordinate to the economic system. His own view, however, was that class structure, together with the distribution of power between classes, determined base-superstructure relations. Thus ideology could be seen in terms of how it reflected the objective interests of a given class rather than by its subservience to the economic base. Hochfeld's approach, therefore, focussed on a key intervening variable (class structure) in the base-superstructure model.

The erudite sociologist Stanislaw Ossowski also underlined the importance of class structure in social development, but he went even further than Hochfeld: 'Study of the conceptions of class structure over centuries has shown that class systems have an enduring ideological superstructure independent of their particular social order'.$^{15}$ Furthermore it was significant to know 'in what respects are the new stages of this new system [socialism], now in the process of stabilisation, accompanied by a revival of the institutions, relationships, psychological attitudes, and ideas of pre-socialist, socio-economic formations'.${ }^{16}$ Economic relations were most influential in affecting class structure in the classic period of capitalism, but under socialism political institutions became more important: 'The planned direction of changes in the social structure and the direct dependence of the economic status of the majority of the population on the state authorities are features that are characteristic of contemporary socialist societies' ${ }^{17}$ The danger posed by the primacy of political institutions in the base-superstructure model was recognized by Ossowski, and though his only explicit references were to the Stalin period which had just come to a close, the general character of his statements suggested it was the socialist system itself which was being taken to task: 'The processes which in mono-party systems came to be called "the estrangement of the party from the masses" showed that it is just as much possible to use class interests as a mask for party interests as it is to disguise class interests by means of universal or national slogans in organisations whose ideology is allegedly not class-bound'. ${ }^{18}$ While ideologies reflecting previous class systems continued to exist, Marxist doctrine, which was intended to

14 Hochfeld, op. cit., p. 172.

15 S. Ossowski, Class Structure in the Social Consciousness, New York 1963, p. 180.

16 Ibid., p. 118.

17 Ibid., p. 184.

18 Ibid., p. 4. 
replace them, became 'in its new form as a state doctrine adapted to further the stabilization of the new regime and to defend the new privileged strata' ${ }^{19}$

In effect what Ossowski did was to employ Stalin's inverted model so as to diagnose the failures of the state socialist system. Indeed, Ossowski says, the superstructure can reject its subordinate role, but with what results-the estrangement of the party from the masses? Certainly only those elements of social consciousness, only those institutions, only that ideology which reflect the current economic order may be accepted as legitimate elements in the superstructure. But how greatly do they then distort the 'current' reality? In Ossowski's work the Stalinist model made one last theoretical contribution: it established its own anti-thesis.

Other scholars also took advantage of the political instability which followed in the wake of the October 1956 events in Poland to challenge various aspects of Marx's theory of social formation. Leszek Kolakowski began to question the whole determinist concept of historic necessity. ${ }^{20}$ Jozef Chalasinski criticized the Stalinist model and concluded that the very principle of a dictatorship of the proletariat was at odds with the Marxian view of the primacy of economic relations. ${ }^{21}$ Andrzej Malewski stressed the importance of the individual, and of his behaviour and attitudes resulting from his experience of concrete situations, and he depreciated the part played by social groups (classes) and social processes. ${ }^{22}$ None of these approaches, however, constituted a fully-developed alternative model: at best each was in an embryonic form. Further development was cut short by party repression of 'revisionism' following Gomulka's consolidation of power. From then on the debate among Polish Marxist scholars continued to be heuristically constructive. But at the same time it became more academic and 'complacent', mirroring the 'little stabilisation' period of the 1960s.

\section{THEORETICAL DIVERSITY AND CONSENSUS}

By the 1960s the voluntarist view of social formation had become so discredited that it no longer generated reaction. In its quest to develop an updated model of base-superstructure relations, Polish sociology returned to primary sources. Considerable theoretical diversity characterized its effort, as we shall see, but simultaneously there was general consensus on the parameters within which any innovative model should

19 Ibid., p. 189.

20 See Kolakowski's articles in Nowa Kultura (1957) and Tworczosc (1959).

21 J. Chalasinski, 'Socjologia i spoleczna mytologia w powojennej Polsce' (unpublished monograph).

22 A. Malewski, 'Empiryczny sens teorii materializmu historycznego', Studia Filozoficzne, 2, 1957, 58-81. 
be located. At the same time some of the analyses were more complex and comprehensive than ever before.

The most systematic study of the issue was carried out by the Poznan philosopher Stanislaw Kozyr-Kowalski. In his early work he strongly polemicized with Lange and argued that, for Marx, it was not congruence but contradictions which characterized the relationship between base, superstructure and social consciousness. The Marxian concept of superstructure, Kozyr-Kowalski contended, included all non-economic institutions, and not simply social consciousness. The latter was most appropriately treated as a 'moment' that formed a part of the superstructure but was not identical with it ${ }^{23} \mathrm{He}$ rejected the view typical of Max Weber and of 'many theorists of the Second International' which equated historical materialism with mechanistic economism. Marxian monism did not differ from 'the theory of historical factors', one form of which was Weber's analysis, in terms of the use of one factor by the former, several by the latter. Their real difference lay in the fact that Marxian monism treated society as a structural whole in which all elements were dynamic and mutually related to each other, but in which they were distinguishable by the significance each had in determining its own character, that of the other elements, and that of the structural whole. An objective in employing the monist model was to discover the mutual dependencies between a given phenomenon and the basic elements making up a society's structure, that is, its economic base, superstructure and social consciousness. 'Marxian monism has nothing in common, therefore, with monocausalism', wrote Kozyr-Kowalski. ${ }^{24}$ Nor did it have anything in common with the subordination of the superstructure to the base, nor with the negation of reciprocal influence between the two.

Kozyr-Kowalski attempted to clear up another main source of misunderstanding surrounding the Marxian model, namely, the concept of political and state institutions which, for most theorists, formed an integral part of the superstructure. The common 'formalist-legal' view was that all activity by political and state institutions should be regarded as superstructural activity. Since the modern state had taken over many economic functions which had previously been performed by free market mechanisms, this view went on to include many state-directed economic processes in the superstructural apparatus. Small wonder, therefore, wrote Kozyr-Kowalski, that some Marxists (like Althusser) saw the state as having superseded economic relations as the decisive factor in affecting social formation. He proposed a different analytical division between base and superstructure: 'The base consists of all general types of productive work and activity which take place in a

23 S. Kozyr-Kowalski, Max Weber a Karol Marks, Warsaw 1967, pp. 486-90.

24 lbid., p. 437. 
society, and the superstructure consists of all general types of nonproductive work and activity going on in that society'. ${ }^{25}$ In this way the increased role of the state in affecting social development did not mean a diminution in the part played by economic relations, for both factors often coincided. What followed logically from this was a division in the kinds of social consciousness appearing in society as well. According to Kozyr-Kowalski, Marx himself suggested as much in The German Ideology when he contrasted material and spiritual activity, each of which had a corresponding type of consciousness. For the Polish Marxist, that consciousness which was indispensable to the performance of productive work appertained to the base; that which was required to engage in non-productive activity belonged to the superstructure. Thus the rigid formalist-legal approach to base and superstructure was substantially overhauled.

A more empirically-oriented study of the subject characterized the work of the political sociologist Jerzy Wiatr. His aim was to give the model relevance to modern industrial socialist and non-socialist societies. In The Marxist Theory of Social Development, he distinguished two fundamental heuristic approaches to social formation. The first consisted of an abstract model of formation which served as an ideal type. The superstructure was composed of all institutions and forms of consciousness which originated in changes in the economic base and served to maintain it. Functionally and genetically they corresponded to the abstract model of economic base. The second approach involved concrete social formations. Their superstructure consisted of the totality of institutions and forms of social consciousness which were affected by changes in the economic base, but which could be either functional or dysfunctional for it. These included institutions and forms of consciousness which corresponded to a specific social formation, those which had survived from earlier formations, and those which were dysfunctional for the extant economic base and could be regarded as the seeds for some future social formation. The economic base was also treated as a totality made up of relations of production characteristic of the current formation, those which had developed during earlier formations, and those which were the embryo of some future formation. ${ }^{26}$ This typology was related to Wlodzimierz Wesolowski's distinction between narrower and broader conceptualizations of base and superstructure, depending on whether only typical and dominant relations of production, forms of consciousness, and institutions in a social formation were considered, or whether the totality of features making up base and superstructure was

25 S. Kozyr-Kowalski, 'Gospodarka a panstwo i swiadomosc spoleczna', Studia Socjologiczne, 3, 1979, 11. Base-superstructure relations were to be the subject of a future study by Kozyr-Kowalski.

26 J. J. Wiatr, Marksistowska teoria rozwoju spolecznego, Warsaw 1973, pp. 113-16. 
taken into account. ${ }^{27}$ Likewise Zygmunt Bauman drew a similar distinction between dominant forms of base and superstructure, and the sum total of all forms. ${ }^{28}$

Wiatr stressed that the theoretical model should not be confused with its 'practical' counterpart, for base-superstructure relations were depicted differently in the two approaches. Thus the classic model posited the primacy of the economic base, but the historical experience of socialist countries had indicated the primacy of changes occurring in the superstructure. ${ }^{29}$ This was explained by the fact that, since the economies of most of these states before their socialist transformation were characterized by low levels of industrialization, political factors took on greater significance. But Wiatr emphasized that the distinction between the 'objective' (socio-economic conditions) and the 'subjective' (social consciousness), between structure and superstructure, existed only at the level of abstraction: 'The separation of man's historical awareness and of ideas concerning his own history from history itself is possible only in theoretical analysis', ${ }^{30}$

For Wiatr base-superstructure relations were marked both by consistencies and contradictions. To the extent that changes in productive forces were reflected in the superstructure, it was possible to speak of congruency. Moreover economic and political elements overlapped: political structures were not simply an outgrowth of economic life, they functioned themselves as economic organisms. ${ }^{31}$ But incongruencies in the relations also appeared. Political factors were dominant in a social formation constructing socialism, but in already highly-advanced socialist societies economic factors tended to reassert their primacy. A similar pattern was diagnosed by the sociologist Jan Szczepanski. ${ }^{32}$

More serious inconsistencies were inherited from the capitalist formation. The most important were contradictions between the base and superstructure of socialist societies and those of rival capitalist societies, those between a socialist economic base and vestiges of the capitalist economic system still in existence in socialist societies (above all, forms of small-scale production), and those between a socialist ideological superstructure and the relicts of bourgeois value systems. ${ }^{33}$ In fact, Wiatr suggested, social consciousness could even find itself at

27 W. Wesolowski, Klasy, warstwy $i$ wladza, Warsaw 1977, pp. 24-29.

28 Z. Bauman, Zarys socjologii, Warsaw 1963, p. 185.

29 J. J. Wiatr, Przycznek do zagadnienia rozwoju spolecznego w formacji socjalistycznej, Warsaw 1979, pp. 53-54.

30 J. J. Wiatr, 'Sociology-Marxism-Reality', Social Research, 34, 1967, 430-31.

31 Wiatr, op. cit., pp. 110-11.

32 J. Szczepanski, 'Spoleczne aspekty industralizacji w Polsce Ludowej', Studia Socjologiczne, 3, 1965, 19-35; Odmiany czasu terazniejszego, Warsaw 1971, pp. 264-65; and Zmiany spoleczenstwa polskiego w procesie uprzemyslowienia, Warsaw 1973, p. 19.

33 Wiatr, op. cit., p. 200. 
loggerheads with political courses pursued in a socialist formation: 'The experience of history has demonstrated that it is possible for cleavage to arise in a socialist state between public opinion and the policy being applied at a given moment by the political leadership' ${ }^{34}$ Such inconsistencies stemmed from the fact that social consciousness tended generally to change more gradually than the socioeconomic base. For Wiatr, therefore, base, superstructure and social consciousness interacted in a very complex way, depending on the social formation in question. Individual factors making up the totality of social life were analytically the most significant, not the totality as such.

Another Polish philosopher, Stanislaw Rainko, also attempted to update the Marxist conception of base and superstructure. In his Consciousness and History, he stated that two fundamental aspects of the historical process could be identified-social existence and social consciousness-in which the first determined the second. Two subcomponents of social existence could also be singled out: the categories of socio-economic base and political-legal superstructure. The base itself was made up of productive forces and productive relations in society, here again the first determining the second. Each entity-the global social totality, social existence and the socio-economic basewas characterized by particular internal mechanisms by which one element to a greater or lesser degree determined another. According to Rainko, therefore, social existence determined consciousness, the base determined the superstructure, and productive forces determined the relations of production. By determination he understood the way in which one factor affected the process, speed and content needed to create another factor. It did not mean that one factor directly created another, for example, that social existence created a corresponding type of consciousness. To determine consciousness meant to decide upon the social success and the effects of its integral ideas. Thus the origin, formation and fate of Marxism as a body of ideas had to be considered in terms of the structure of social history which allowed it to develop. In the case of Marxism, however, not only was it shaped by history, it also exerted its own influence on future social development. ${ }^{35}$

In many respects Rainko's approach signalled a return to a more traditional interpretation of Marx's theory of social formation. For he outlined a chain of influence leading from productive forces through the economic base to social consciousness and the superstructure. By the 1970 s when Rainko was writing, however, the dominant approach in Polish Marxist sociology was to emphasize the reciprocity of influence along the chain.

Rainko also rejected 'the rather liberal proposition' of viewing determination in a very flexible way, which he alleged was characteristic of,

34 J. J. Wiatr, Socjologia stosunkow politycznych, Warsaw 1977, p. 528.

35 S. Rainko, Swiadomosc i historia, Warsaw 1978, pp. 25-32, 209. 
amongst others, representatives of the Poznan school. ${ }^{36}$ Although not a member of this philosophical school, Daniel Markowski did adopt a 'rather liberal' approach in his empirical study of social consciousness. For he concluded that fundamental changes occurring in the economic base did not automatically lead to a transformation of that part of the superstructure composed of social consciousness. In fact he argued that the thesis that social consciousness corresponded to material existence should be rejected. Many aspects of consciousness consisted of 'metaattitudes' such as individualism, instrumentalism and traditionalism, which were sometimes treated as deviations in a socialist system. Markowski argued that social consciousness had to be seen as a multi-stage formative process which, in addition to material conditions, was affected by a number of other factors, for example, state institutions, political heritage and intellectual orientations. ${ }^{37}$

The political scientist Artur Bodnar also focussed on the multidirectional and dynamic nature of base-superstructure relations in a socialist state. While it was true that the superstructure was often a function of the economic order, it was also more elastic and malleable. It also fed back on the base so that relations between it, productive forces and the relations of production did not follow a determined spatial-time sequence. Not all socialist states, Bodnar noted, had reached the same stage of socialist development; this was due in part to the absence of an internal equilibrium between these elements. Some states still display a low level of development in their productive forces, others had not completed socializing the means of production, while in others still socialist values had not yet been fully internalized by large segments of the population, nor had 'mature forms of socialist democracy' been attained. But, according to Bodnar, political factors would ensure that all socialist countries would soon reach 'advanced socialism'. For in any kind of socialist formation they were 'superior' to economic factors. He called this phenomenon a sociological law of socialism. ${ }^{38}$

What is most characteristic of the approaches to base-superstructure relations in the post anti-Stalin period is the almost universal emphasis on the dialectical, or dynamic, interaction between the two. Although Kozyr-Kowalski and Rainko re-emphasized the primacy of productive or material forces, in general Polish Marxists saw the relationship in terms of what Jerzy Topolski called 'synchronic-diachronic' (or

36 S. Rainko, 'A Few Theses on Historical Materialism', Polish Sociological Bulletin, 2, 1979, 5-17. The Poznan school to which he refers is concerned primarily with developing a modern Marxist approach to historical epistemology. Its leading exponents are Jerzy Kmita and Leszek Nowak.

37 D. Markowski, Rozwoj a swiadomosc spoleczna, Rzeszow 1979, pp. 85-100.

38 A. Bodnar, Ekonomia i polityka, Warsaw 1978, p. 247; 'Problemy interpretacji jednosci ideologii, ekonomiki i polityki', in W. Noska (ed.), Jednosc ideologii, ekonomiki i polityki, Warsaw 1979, p. 59. 
structural-directional) regularities. That is, firstly 'the system which functions as the cause and the system upon which the former system acts are interconnected synchronically, that interconnection being reinforced by a feedback', and secondly, 'A pure directional regularity sets a system in motion. .., it assumes a constant inflow of energy which is to ensure prospective (in the sense of: future oriented) operation of that system' ${ }^{39}$ For the Polish theorists we considered, historical development was based on the dual nature of these regularities, not on a purely diachronic, causal relationship between productive forces and superstructure, as some Western critics infer. And although this organic approach has sailed a safe enough course between the Scylla of determinism and the Charybdis of voluntarism, it seems then to have rammed into a third obstacle: conceptual obsolescence. For the synchronicdiachronic model did not possess the explanatory capacity to account for the uncharted 'drift' that took place in Polish society under the Gierek leadership.

\section{TOWARDS A MODEL OF AN UNPLANNABLE SOCIALIST SOCIETY?}

All would have been well with some of the sophisticated approaches to base-superstructure relations expounded by Polish Marxists if but one condition had been met: that in that society at least some $A$ sometimes determined some $B$. Social and economic developments in Poland in the nineteen-seventies seemed to cast doubt whether this ever occurred. Despite a well-polished veneer of planning, the economic system was more dependent on its ability to adapt to spontaneous incentives than on carrying out central directives. ${ }^{40}$ Fetishization of planning methods led to market disequilibrium and impotence in introducing technical innovations. ${ }^{41}$ Society was characterized by the "self-reproduction of artificial reality': almost any organisational concepts, forms or rules could be introduced, but they immediately became objectified and reified. Every new programme was presented as being 'objectively true'-until the next change. Nothing was really planned for, therefore, except political crises. ${ }^{42}$

These observations, drawn by critics of the nineteen-seventies drift, are not directly related to the issue of social formation. But they contain the rudiments with which new theories would have to begin. For the analytical tools which Polish sociologists had been trained to use have become unfit for the job at hand: to describe the logistics governing

39 J. Topolski, Methodology of History, Warsaw 1976, p. 287.

40 W. Narojek, Spoleczenstwo planujace, Warsaw 1973.

41 J. Beksiak, Spoleczenstwo gospodarujace, Warsaw 1976.

42 J. Staniszkis, 'Dialektyka spoleczenstwa socjalistycznego' (unpublished monograph). See also her 'On Some Contradictions of Socialist Society: The Case of Poland', Soviet Studies, 31, 1979, 167-87. 
social formation in a society attempting to reach advanced socialism. It may be some time before relevant models are constructed, so it might prove valuable to look briefly at theories formulated by two Polish social scientists now living in the West.

In his Socialist Ownership and Political Systems, the economist Wlodzimierz Brus described a trend line along which various economic systems could be situated. For example, state intervention in capitalist economies represented a new and higher stage in the evolution of the relations of production. Its consequences were the politicization of the economy and a reversal of earlier relations between economic base and political superstructure. He departed further from the conventional Marxist model by suggesting that socialism was a systemic formation located further along the trend line from capitalism. That is, he perceived continuity of development between capitalism and socialism in contrast to Marxists, who treated socialism as a separate formation, or the English economist Robinson, who regarded socialism as a substitute for capitalism. ${ }^{43}$ In socialist countries, Brus argued, political institutions influenced the economic structure in two ways: firstly, at an early stage, by the large-scale nationalization of the means of production and, secondly, by central planning later on. Nationalization carried out in socialist countries had altered their economic structure and their social and political relations, but it had not socialized ownership, that is, society did not yet possess effective disposition over the means of production. For Brus socialized ownership would completely reverse base-superstructure relations since it would originate in the relations of power in that society. In short, socialist relations of production would be determined by political and power relations. But since socialized ownership did not yet exist in these states, productive forces continued to play the decisive role in social formation. ${ }^{44}$

From his vantage point in England, Bauman too considered the relevance of the Marxist model of social formation to socialist systems. He concluded that the most that could be said about the determining role of material conditions was that they set limits to ideas which could be used to account for these conditions. Citing Gramsci he noted that it was the degree of adequacy that made the adoption of some ideas more probable than that of others. The immanent contradiction in the Marxist model was, however, its assumption, on the one hand, of the essential openendedness of the human situation, and an overwhelming tendency, on the other hand, to close it off empirically by unveiling its historical determinants. As a result, there developed a co-existence between critical thought and criticized reality, between the 'utopian thrust and the recalcitrant "actuality", institutionalizing and effectively protecting

43 W. Brus, Socialist Ownership and Political Systems, London 1975, pp. 10-13. 44 Ibid., p. 209. 
the former telos' ${ }^{45}$ The search for the missing link leading from reality to utopia lay at the roots of the Marxist theory of inevitability. For commonsense, overawed by an all-powerful reality, will bow only to an even more powerful and more "real" reality'.46

Whereas Brus employed a modified version of the basesuperstructure model to describe social formations, Bauman was concerned more with the psychology underlying the popularity of the theory. The first tried to give it relevance, the second to explain its attractiveness and endurance. In very different ways each demonstrated the indispensability of the model in state socialist societies.

\section{CONCLUSION}

This brief examination of approaches taken by Polish Marxist-trained social scientists to the Marxist model of social formation has tried to indicate the similarities and dissimilarities that have appeared in their work. We have noted considerably more diversity in views than Western critics usually acknowledge. Moreover, approaches have changed in time with objective socio-political conditions in Poland. From the controversy surrounding the Stalinist model during the late nineteen fifties, the emphasis shifted to synchronic-diachronic approaches in the next two decades. A central issue in attempts to modify the classic model was how to explain determinance stemming from both a transformed economic base, and from the party's position as the leading directive force in society. Increasingly the primacy of economic factors was questioned: this theory was expendable. The doctrine of the party's leading role could not be challenged and there were, therefore, few attempts to negate the influence of the superstructure on social formation. By the late nineteen seventies, different approaches were discernable which tried to account for the part played by unplanned, spontaneous social and economic mechanisms operating in the socialist system. But it would be safe to say that no theory foresaw or could account for the turn of events in Poland during 1980-81.

We can suggest, therefore, that theories of base-superstructure relations, describing the reciprocal influence between material conditions and political and ideological factors, seem themselves to be a function of the political and ideological circumstances dominant at a particular time. This would help substantiate the sociologist Jan Strzelecki's observation that "Marxism is not a vehicle out of which it is possible to step at any time. This means that the famous principle "social existence determines thought" applies equally to socialists and Marxists' ${ }^{\prime 7}$-and to social scientists no less.

45 Z. Bauman, Socialism-The Active Utopia, New York 1976, p. 71.

46 Ibid., p. 139.

47 J. Strzelecki, Kontynuacje (2), Warsaw 1974, p. 80. 
The debate has been animated and disagreement often fundamental. One writer could argue that there had to be congruency between social consciousness and the material base (Lange), another could claim that even under socialism the two could be at odds with each other (Wiatr). One could propose that the political structure had become the most influential factor shaping social formation (Brus), another could state that economic forces were regaining their ascendency (Szczepanski). The constituent elements making up the classic model were defined, weighted and combined differently too. For one theorist the productive or non-productive nature of activity determined its place in the model (Kozyr-Kowalski). For another the categories of socio-economic base and political-legal superstructure were grouped together to constitute social existence (Rainko). For two sociologists, class structure was the key variable in the model (Hochfeld, Ossowski), for another it was the internal equilibrium of productive forces, relations of production and superstructure (Bodnar). Where there was general agreement on the model, it was to do with its intrinsic importance as a still valid (if considerably modified) framework of analysis for social formations, and as a utopian thrust (Bauman). To this extent Polish social scientists either remained faithful to the methodological approach of Marxism, or they ceased to be social scientists in Poland.

This survey of Polish sociological thought concerning the theory of social formation shows how inaccurate it is to conclude, as Kolakowski does, that when Marxism, after having been isolated for decades from other ideas, finally came into contact with external ideas, it was too late and 'the doctrine collapsed, like mummified remains suddenly exposed to the air'. ${ }^{48} \mathrm{He}$ is also wrong when he states that 'There is probably no part of the civilized world in which Marxism has declined so completely and socialist ideas have been so discredited and turned to ridicule as in the countries of victorious socialism' ${ }^{49}$ The contributions of Polish social scientists to the Marxist model we considered indicate that, for some time to come yet, Marxism is unlikely to turn into a mummy.

What Jordan noted, therefore, about the attempts of Polish political scientists to make sense of the Marxist notion of ideology can apply equally to their efforts to give life to the well-worn base-superstructure model: 'In conclusion it is only fair to emphasise the considerable amount of intellectual energy which Polish Marxist-Leninists had to spend on clarifying the inherited doctrine of ideology and on extracting themselves from the entangling web of transparent fallacies and gross errors, some of which still haunt Marxist-Leninist thinking' ${ }^{50}$

At the same time it is true that theoretical innovations in this area have not kept pace with the recent political changes sweeping Poland. To a

48 L. Kolakowski, Main Currents of Marxism, Vol. 3, Oxford 1978, p. 465.

49 Ibid., p. 474.

50 Jordan, op. cit., pp. 500-501. 
large extent this is a result of the ideological constraints under which Polish theorists had to operate, which made it wiser for them to describe the mechanisms and diagnose the defects of social formations other than the one in which they lived. But the gap between theory and Poland's suddenly-transformed political circumstances could also be attributed to the basic incompatibility of Marxism with political power-sharing under socialism. In applying, for example, the base-superstructure model to the country's political conditions in 1980-81, we could not even resolve the issue whether the syndicalist consciousness of 'Solidarity' represented a product of the material conditions in existence during the Gierek period, or whether it arose spontaneously to change them. In effect, either the model of social formation was now redundant, or the changed political circumstances had to disappear. 